\title{
Gastropoda, Pulmonata, Helicidae, Cepaea nemoralis (Linnaeus, 1758): New records for Montreal, Canada
}

\author{
Aydin Örstan \\ Carnegie Museum of Natural History, Section of Mollusks. 4400 Forbes Avenue. Pittsburgh, PA, 15213-4080, Unites States of America. \\ E-mail: pulmonate@earthlink.net
}

\begin{abstract}
The European land snail Cepaea nemoralis (Linnaeus, 1758) was introduced in North America in 1857 in Burlington, New Jersey, U.S.A. There is only one anedoctal record of $C$. nemoralis from Montreal, Canada, but without a date or an exact location. In this note, recent records of $C$. nemoralis are presented for Montreal, based on surveys from 7 to 9 August 2009 along a southwest to northeast transect parallel to the Montreal-Dorion-Rigaud commuter railroad.
\end{abstract}

The earliest recorded introduction of the European land snail Cepaea nemoralis (Linnaeus, 1758) in North America was by William G. Binney and took place in 1857 in Burlington, New Jersey, U.S.A. (Gould and Binney 1870). There have since been other intentional and unintentional introductions from Europe and also within North America, resulting in the accumulation of records of $C$. nemoralis from many sites in the U.S.A. and Canada (La Rocque 1962; Reed 1964; Dundee 1974; Forsyth 1999). Robinson (1999) listed C. nemoralis as a "travelling species" that is often confiscated at airports from the passengers coming to the U.S.A. from Europe. The occasional discoveries of colonies in places where the species was not seen before (for example, Whitson 2005) may be an indication that C. nemoralis is slowly dispersing itself throughout North America.

There are two published 19th century records of $C$. nemoralis from Canada; one of these was from Anticosti Island, Quebec, while the other was from a sample dredged near Caribou Island in Southern Labrador (La Rocque 1962; Reed 1964). But those may have been based on specimens of the similar $C$. hortensis, which has established and possibly native populations in coastal areas of northeast North America (Dundee 1974; Hubricht 1985). Pilsbry (1928) gave a record of $C$. nemoralis from Owen Sound, Ontario that he thought was the first Canadian record of the species. The Carnegie Museum of Natural History, Pittsburgh, Pennsylvania, U.S.A. has one lot of $C$. nemoralis (CM 100457) that was collected in Cape Rouge, Quebec in 1890. According to the collector, the snails at that location had originally been introduced from Laurdes, France in 1884. Neither La Rocque (1962), nor Reed (1964), nor Dundee (1974) cited a record of $C$. nemoralis from Montreal, Quebec. The only published record of $C$. nemoralis from Montreal seems to be the anecdotal record Grimm (1996) gave without stating when and where in the city the species had been found. I present here recent records of $C$. nemoralis from Montreal, Canada.
I searched for snails on 7-9 August 2009 along a southwest to northeast transect parallel to the MontrealDorion-Rigaud commuter railroad in Montreal. All searches were done under railroad bridges or along public roads alongside the railroad tracks; the fencedin restricted zone adjacent to the railroad was excluded from the survey. The coordinates were obtained with a GPS receiver and subsequently corrected, when necessary, using Google Earth. I found $C$. nemoralis at the following localities (Figure 1).

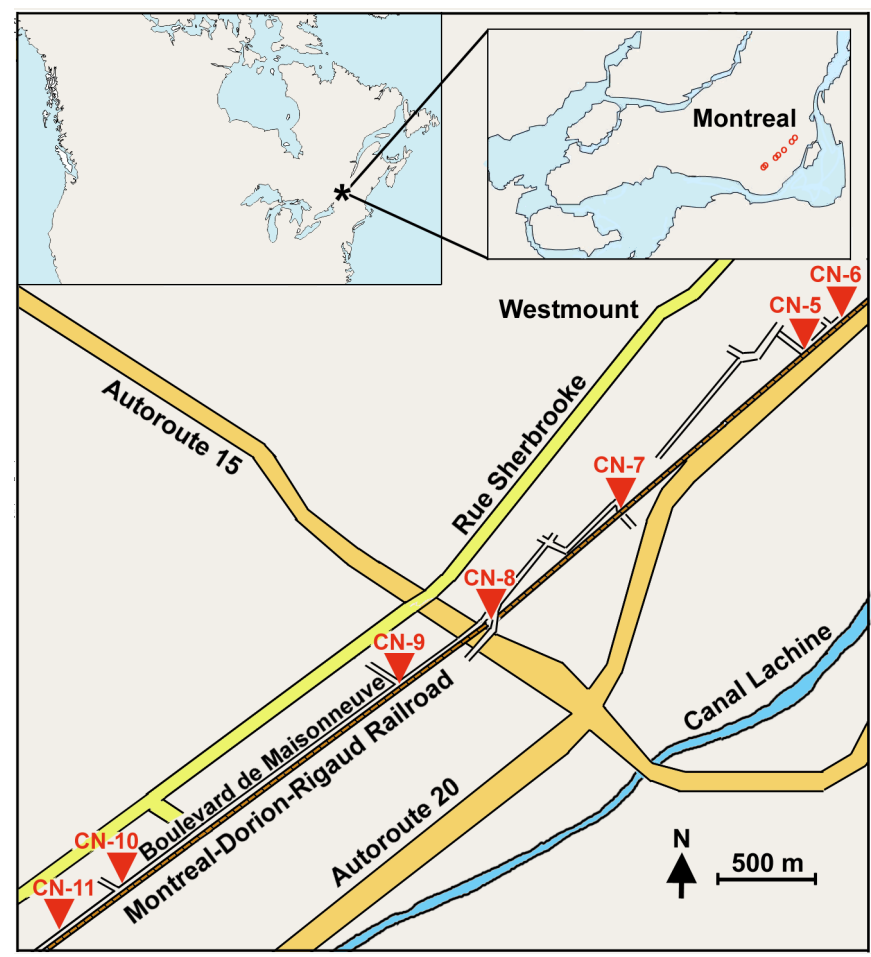

FigurE 1. Map of the collection localities along the Montreal-DorionRigaud railroad in Montreal, Canada. Only the major roads near the collection localities are shown. 
CN-5: Under the railroad bridge at the intersection of Avenue Greene and Rue Prospect; 4529'4.8” N, 7335'6.2” W. 8 August 2009.

CN-6: Large parking lot next to the railroad at the end of cul-de-sac off of Avenue Clandeboye; 45⒉'11" N, 7334'57" W. 8 August 2009.

CN-7: Under the railroad bridge on Chemin Glen; 4528'37.4" N, 73³5'50.4" W. 7 August 2009.

CN-8: On grassy strip along railroad fence on Boulevard de Maisonneuve Ouest; 45²8'19.9” N, 73³6'22.8” W. 9 August 2009.

CN-9: On grassy strip along railroad fence at the intersection of Maisonneuve and Avenue Harvard; 4528'8.9" N, 7336'44" W. 9 August 2009.

CN-10: On grassy strip along railroad fence at the intersection of Maisonneuve and Rue Park Row West; 4527'34.1" N, 73³7'51" W. 9 August 2009.

CN-11: On grassy strip along railroad fence on Maisonneuve, across from Concordia University soccer field; 45²7'26.3" N, 73³8'6.0” W. 9 August 2009.

The distance covered during this survey between the northeastmost locality $\mathrm{CN}-6$ and the southwestmost locality CN-11, estimated from Google Earth, was $5.2 \mathrm{~km}$. I saw live $C$. nemoralis at localities $\mathrm{CN}-5, \mathrm{CN}-7$ and $\mathrm{CN}-10$ and fresh shells at all localities. There were dormant snails on the walls of the railroad bridges at localities $\mathrm{CN}-5$ and $\mathrm{CN}-7$ (Figure 2). One dormant snail was $\sim 3.5 \mathrm{~m}$ above the ground.

Shell colors and banding patterns of C. nemoralis are highly variable (Kerney and Cameron 1979). This variability has been the subject of many studies (for a recent review, see Cook 2008). The specimens seen or collected in Montreal included shells with either pink or yellow backgrounds and unbanded shells, as well as shells with 1, 3 and 5 bands (Figure 2). However, the small number of specimens $(<12)$ seen at the Montreal localities ruled out statistically meaningful comparisons of shell colors and banding patterns between different sites. I deposited voucher specimens from locality $\mathrm{CN}-7$ in the Carnegie Museum of Natural History (CM100500).

Kerney and Cameron (1979) noted that the habitat of $C$. nemoralis in Europe is varied and includes woods, hedges and grassland. Boycott (1934) included roadside and railroad banks among the habitats of $C$. nemoralis in Great Britain. Boycott also classified C. nemoralis as a species that prefers calcareous habitats, but which can also be found in non-calcareous places. The broad habitat

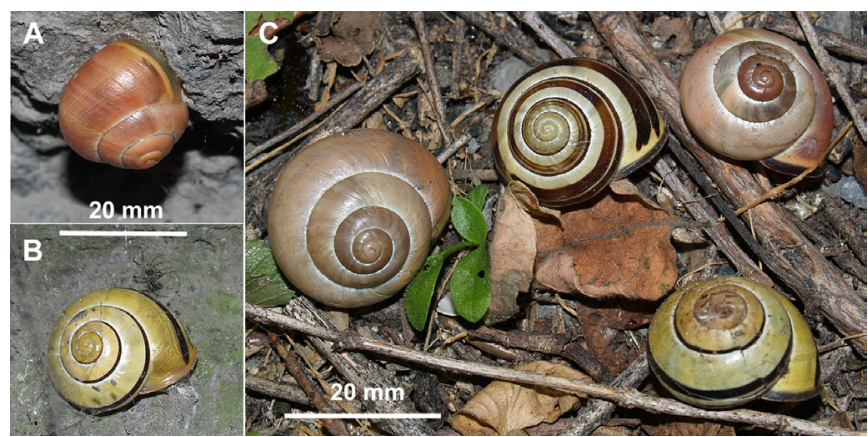

FIGURE 2. Variation of Cepaea nemoralis at locality CN-7. A: Pink bandless morph dormant on the wall of the railroad bridge. B: Yellow morph with one band dormant on the same wall. A small spider was building its web over the shell. C: Empty shells. requirements of $C$. nemoralis in Europe suggest that the narrow $(\sim 10 \mathrm{~m})$ strip of land extending along the railroad in Montreal, having been overgrown with small trees, ivies and various herbaceous plants, is a suitable habitat for $C$. nemoralis (Figure 3). Furthermore, the common use of crushed limestone as ballast under railroad ties must have turned the immediate vicinity of the railroad into a calcareous habitat even if the underlying soil was originally low in calcium carbonate.

Trains may be directly responsible for the dispersal of the snails that live near railroads if the snails climb on train cars and are then transported to other locations along the railroads. Transport of railroad materials (ties, limestone) along railroads for repairs and maintenance may also help disperse the snails that live close to the railroads. It is likely that $C$. nemoralis is present along other railroads that pass through Montreal, and perhaps also at other suitable locations, for example, gardens and parks, in the city.

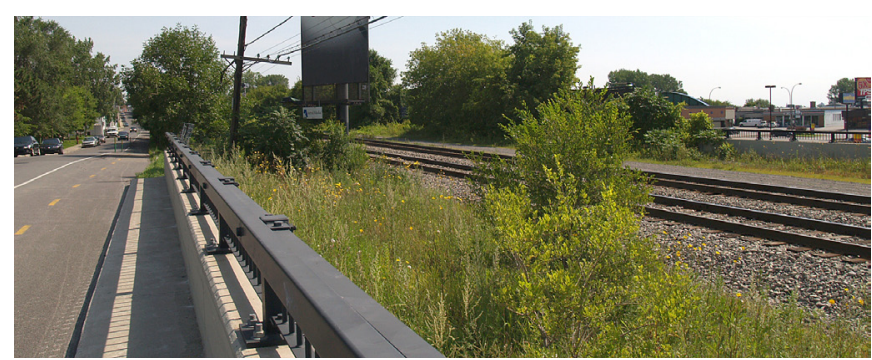

FIGURE 3. The typical habitat of Cepaea nemoralis along the MontrealDorion-Rigaud railroad in Montreal, Canada. The picture was taken from Boulevard de Maisonneuve Ouest.

\section{Literature Cited}

Boycott, A.E. 1934. The habitats of land Mollusca in Britain. Journal of Ecology 22: 1-38.

Cook, L.M. 2008. Variation with habitat in Cepaea nemoralis: the Cain \& Sheppard diagram. Journal of Molluscan Studies 74: 239-243.

Forsyth, R.G. 1999. Distributions of nine new or little-known exotic land snails in British Columbia. The Canadian Field-Naturalist 113: 559568.

Gould, A.A. and W.G. Binney. 1870. Report on the Invertebrata of Massachusetts. Boston: Wright and Potter. 524 p.

Grimm, F.W. 1996. Terrestrial mollusks. In: I.M. Smith (ed.). Assessment of species diversity in the mixedwood plains ecozone. Ecological Monitoring and Assessment Network, Canada. Accessible at http:// www.naturewatch.ca/MixedWood/landsnai/. Accessed on 14 September 2009.

Hubricht, L. 1985. The distributions of the native land mollusks of the eastern United States. Fieldiana 24: 1-191.

Dundee, D.S. 1974. Catalog of introduced molluscs of eastern North America (North of Mexico). Sterkiana 55: 1-37.

Kerney, M.P. and R.A.D. Cameron. 1979. A field guide to the land snails of Britain and north-west Europe. London: Collins. 288 p.

La Rocque, A. 1962. Checklist of the non-marine mollusca of Quebec. Sterkiana 7: 23-44.

Pilsbry, H.A. 1928. Helix nemoralis L. in Ontario. Nautilus 42: 42-43.

Reed, C.F. 1964. Cepaea nemoralis (Linn.) in eastern North America. Sterkiana 16: 11-18.

Robinson, D.G. 1999. Alien invasions: the effects of the global economy on non-marine gastropod introductions into the United States. Malacologia 41: 413-438.

Whitson, M. 2005. Cepaea nemoralis (Gastropoda, Helicidae): The Invited Invader. Journal of the Kentucky Academy of Science 66: 82-88.

RECEIVED: November 2009

REVISED: January 2010

ACCEPTED: February 2010

Published ONLINE: February 2010

EDITORIAL RESPONSIBILITY: Inga Ludmila Veitenheimer Mendes 